\title{
SISTEM INFORMASI PENGUKURAN KEPUASAN PELANGGAN MENGGUNAKAN METODE IMPORTANCE PERFORMANCE ANALYSIS PADA PROGRAM STUDI MANAJEMEN INFORMATIKA
}

\author{
Zeini Ikrawan $^{1}$, Yuri Ariyanto ${ }^{2}$, Budi Harijanto ${ }^{3}$ \\ 1,2 Jurusan Teknik Elektronika, Program Studi Teknik Informatika, Politeknik Negeri Malang \\ ${ }^{1}$ Ikrawan17@yahoo.com, ${ }^{2}$ yuri.bjn@gmail.com, ${ }^{3}$ Budi.hijet@gmail.com
}

\begin{abstract}
Abstrak
Pendidikan merupakan jasa yang berupa proses pembudayaan, pengertian ini berimplikasi adanya input dan output. Inputnya adalah peserta didik atau mahasiswa, sarana, prasarana dan lingkungan, sedangkan outputnya adalah jasa pelayanan pendidikan, lulusan dan alumni. Perkembangan dunia pendidikan tinggi sekarang ini semakin luar biasa, hal ini ditandai dengan banyaknya perguruan tinggi baru yang secara otomatis semakin meningkatkan persaingan antar perguruan tinggi yang ada.Program Studi Manajemen Informatika merupakan salah satu program studi yang ada pada Politeknik Negeri Malang yang juga ikut berperan dalam perkembangan dunia pendidikan di kota Malang. Sebagai Program Studi yang telah menghasilkan banyak lulusan, maka perlu diadakan penelitian untuk melakukan evaluasi tehadap berbagai aspek yang mempengaruhi kepuasan alumninya, hal ini dimaksudkan agar Program Studi mengetahui sampai sejauh mana kualitas pelayanan yang telah diberikan kepada para mahasiswa dan untuk melakukan peningkatan kualitas pelayanan dan pembelajaran,maka digunakan Importance-Performance Analysis (John A. Martila and Jhon C. James,1977: 77-79) atau Analisa Tingkat Kepentingan dan Kinerja/Kepuasan Pelanggan. Namun dalam pengumpulan data penilaian tingkat kepentingan dan tingkat kinerja/kepuasan yang kurang efisien, dari hambatan tersebut perlu dibuat suatu sistem secara online sehingga memberi kecepatan, keakuratan dan efisiensi waktu dalam proses pengolahan data dan informasi. Dalam skripsi ini membahas tentang bagaimana membuat aplikasi yang bisa mengukur sampai sejauh mana kepuasan alumni terhadap pelayanan tersebut dengan menggunakan metode Importance Performance Analysis. Setelah aplikasi diuji coba kepada alumni program studi manajemen informatika untuk mengisi atribut kuesioner tingkat kepentingan dan tingkat kinerja / kepuasan, sistem menghasilkan informasi persentase kepuasan alumni terhadap atribut kuesioner yang mempengaruhi kepuasan alumni, informasi rangking atribut kuesioner dan tingkat prioritas perbaikan atribut kuesioner, yang nantinya informasi yang dihasilkan menjadi bahan pertimbangan Program Studi Manajemen Informatika dalam memprioritaskan perbaikan pelayanan yang dirasa kurang memuaskan oleh pelanggan dalam hal ini alumni.
\end{abstract}

Katakunci: Kepuasan Alumni, Importance Performance Analysis.

\section{PENDAHULUAN}

\subsection{Latar Belakang}

Pendidikan merupakan jasa yang berupa proses pembudayaan, pengertian ini berimplikasi adanya input dan output. Inputnya adalah peserta didik atau mahasiswa, sarana,prasarana dan lingkungan, sedangkan outputnya adalah jasa pelayanan pendidikan, lulusan dan alumni. Perkembangan dunia pendidikan tinggi sekarang ini semakin luar biasa, hal ini ditandai dengan banyaknya perguruan tinggi baru yang secara otomatis semakin meningkatkan persaingan antar perguruan tinggi yang ada.
Kompetensi adalah kemampuan individu dalam melaksanakan tugas-tugas profesinya yang merupakan perpaduan pengetahuan, ketrampilan dan sikap. Spencer and Spencer (1993) mengemukakan kompetensi adalah kapasitas dari pengetahuan, keterampilan, dan sikap yang dimiliki oleh seorang karyawan yang relevan dengan standar pekerjaan yang akan dilakukan sehingga mampu melaksanakan pekerjaan yang telah dirancang bagi dirinya baik untuk saat ini maupun di masa yang akan datang. Pada organisasi jasa termasuk pendidikan tinggi,produk jasa diterima oleh pelanggan pada saat terjadi interaksi antara dosen dengan penerima jasa (mahasiswa), sehingga kompetensi dosen dan kualitas proses pembelajaran 
dalam bekerja sangat menentukan kualitas produk jasa yang dihasilkan.

Program Studi Manajemen Informatika merupakan salah satu program studi yang ada pada Politeknik Negeri Malang yang juga ikut berperan dalam perkembangan dunia pendidikan di kota Malang.Sebagai Program Studi yang telah menghasilkan banyak lulusan, maka perlu diadakan penelitian untuk melakukan evaluasi tehadap berbagai aspek yang mempengaruhi kepuasan alumninya, hal ini dimaksudkan agar Program Studi mengetahui sejauh mana kualitas pelayanan yang telah diberikan kepada para mahasiswa dan untuk melakukan peningkatan kualitas pelayanan dan pembelajaran.

Kepuasan pelanggan merupakan evaluasi spesifik terhadap keseluruhan pelayanan yang diberikan pemberi jasa, sehingga kepuasan pelanggan hanya dapat dinilai berdasarkan pengalaman yang pernah dialami saat proses pemberian pelayanan.Menurut Kotler (2003), kepuasan merupakan perasaan senang ataupun kecewa seseorang yang berasal dari perbandingan antara kesannya terhadap kinerja (atau hasil) suatu produk dan harapan-harapannya.Apabila kinerja lebih kecil dari harapan konsumen akan merasakan tidak puas.Apabila kinerja sama dengan harapan konsumen akan merasakan puas.Apabila kinerja melebihi harapan, konsumen akan merasakan sangat puas.

Program Studi Manajemen Informatika memiliki komitmen untuk menghasilkan layanan pendidikan yang bermutu,terus memperbaiki dan memenuhi harapan pelanggannya. Untuk itulah penelitian ini diperlukan, data yang diperoleh akan dipergunakan untuk mengukur sampai sejauh mana tingkat kepuasan alumni terhadap kinerja Pelayanan sebagai bahan evaluasi proses pelayanan di Program studi manajemen informatikasehingga dapat meningkatkan mutu pelayanan di Program Studi Manajemen Informatika politeknik Negeri Malang.

Teknik analisis data yang dipergunakan analisis tingkat kepentingan kualitas pelayanan ImportancePerformace Analysis. Umar (2002:251) menyebutkan Importance-Performance Analysis banyak digunakan dalam mengukur tingkat kepuasan pelanggan berdasarkan elemen-elemen dari harapan-harapan atas sesuatu yang menjadi kepentingan konsumen dan kenyataan-kenyataan yang diterima konsumen. Analisis tingkat kepuasan ini dilakukan dengan memplot nilai rata-rata kepentingan dan nilai rata-rata kenyataan pada diagram Kartesius.

Adanya hambatan dalam pengumpulan data dan kurang efisien waktu dalam menganalisis data tingkat kepentingan kualitas pelayanan Importance-
Performace Analysis maka diperlukan sebuah sistem informasi yang diharapkan memberi kecepatan ,keakuratan dan efisiensi waktu dalam proses pengolahan data untuk mengetahui tingkat kesesuaian antara tingkat kepuasan dan tingkat harapan alumni terhadap layanan pendidikan pada program studi manajemen informatika Politeknik Negeri Malang yang ditampilkan dengan atribut pertanyaan,selanjutnya dari hasil tingkat kepuasan dan tingkat harapan dapat diperoleh informasi tingkat prioritas perbaikan atribut pertanyaan yang mana yang harus diprioritaskan untuk perbaikan menurut penilaian kepuasan/kinerja dan nilai kepentingan/harapan.

\section{LANDASAN TEORI}

\subsection{Konsep Kepuasan dan Pengukuran Kepuasan Pelanggan Kepuasan}

Kepuasan (satisfaction) berasal dari bahasa latin yaitu satis yang berarti enough atau cukup dan facere yang berarti to do atau melakukan. Sebuah kepuasan juga dapat didefinisikan sebagai persepsi terhadap sesuatu yang telah memenuhi harapannya. Oleh karena itu, seseorang tidak akan puas apabila mempunyai persepsi bahwa harapannya belum terpenuhi. Seseorang akan merasa puas jika persepsinya sama atau lebih besar dari yang diharapkan (Irawan, 2003).

Kotler (2002) menyatakan bahwa kepuasan adalah perasaan seseorang setelah membandingkan kinerja atau hasil yang dirasakan dengan harapannya. Sedangkan menurut Chaplin (2005) kepuasan adalah satu keadaan kesenangan dan kesejahteraan yang disebabkan karena seseorang telah mencapai suatu tujuan atau sasaran. Dalam konteks perilaku konsumen, kepuasan ditujukan pada individu atau kelompok terhadap apa yang dikonsumsinya yaitu produk barang atau jasa.

Kepuasan adalah hasil dari penilaian konsumen bahwa produk atau jasa telah memberikan tingkat kenikmatan dimana tingkat pemenuhan ini lebih atau kurang (Irawan, 2003)

Wilkie mendefinisikan kepuasan sebagai suatu tanggapan emosional pada evaluasi terhadap pengalaman konsumsi suatu produk atau jasa (Tjiptono, 1996). Sedangkan Saladin (2003) mendefinisikan kepuasan konsumen sebagai perasaan senang atau kecewa konsumen yang berasal dari perbandingan antara kinerja (hasil) suatu produk dengan harapannya.

\subsection{Pelanggan}


Pelanggan adalah seseorang yang menjadi terbiasa untuk membeli yang terbentuk melalui perubahan dan interaksi yang sering selama periode waktu tertentu (Griffin, 2005). Dalam pengertian sehari-hari pelanggan adalah orang- orang yang kegiatannya membeli dan menggunakan suatu produk, baik barang maupun jasa, secara terus menerus. Pelanggan atau pemakai suatu produk adalah orang-orang yang berhubungan secara langsung maupun tidak langsung dengan perusahaan-perusahaan bisnis. Adapun pihak-pihak yang berhubungan dan bernegosiasi dengan perusahaan-perusahaan bisnis sebelum tahap menghasilkan produk dinamakan pemasok. Dilihat dari segi perbaikan kualitas, definisi pelanggan adalah setiap orang yang menuntut pemberian jasa (perusahaan) untuk memenuhi suatu standar kualitas pelayanan tertentu, sehingga dapat memberi pengaruh pada performance pemberi jasa (perusahaan) tersebut. Dengan kata lain, pelanggan adalah orang-orang atau pembeli yang tidak tergantung pada suatu produk, tetapi produk yang tergantung pada orang tersebut. Oleh karena pelanggan ini pembeli atau pengguna suatu produk maka harus diberi kepuasan.

\subsection{Kepuasan Pelanggan}

Kepuasan pelanggan adalah suatu kondisi, dimana kebutuhan, keinginan, dan harapan konsumen terhadap sebuah produk dan jasa, sesuai atau terpenuhi dengan penampilan dari produk dan jasa. Konsumen yang puas akan mengkonsumsi produk tersebut secara terus menerus, mendorong konsumen loyal terhadap produk dan jasa tersebut dan dengan senang hati mempromosikan produk dan jasa tersebut dari mulut ke mulut (Brown, 1992).

Kepuasan pelanggan adalah perasaan kecewa atau senang seseorang yang muncul setelah membandingkan antara persepsi atau kesan terhadap kinerja atau hasil dari suatu produk dan harapan harapannya (Kotler, 2004). Suatu pelayanan dinilai memuaskan apabila pelayanan tersebut dapat memenuhi kebutuhan dan harapan pelanggan. Pengukuran kepuasan pelanggan merupakan elemen penting dalam menyediakan pelayanan yang lebih baik, lebih efisien dan lebih efektif. Apabila pelanggan merasa tidak puas terhadap suatu pelayanan yang diberikan, maka pelayanan tersebut sudah dipastikan tidak efisien dan tidak efektif. Tingkat kepuasan pelanggan terhadap pelayanan merupakan faktor yang penting dalam mengembangkan suatu sistem penyediaan pelayanan yang tanggap terhadap kebutuhan pelanggan.
Setiap perusahaan yang berorientasi pada pelanggan perlu menyadari bahwa menjaga kepuasan pelanggan dan kesediaannya untuk bekerjasama tidak cukup hanya dengan menerapkan aturan baku yang ada dalam perusahaan, akan tetapi juga terletak pada bagaimana perusahaan tersebut memperlakukan pelanggannya. Jika pelanggan semakin merasa bahwa pelanggan tersebut sedang tidak ada ditempat yang asing dikala pelanggan sedang berinteraksi dengan perusahaan, maka akan semakin besar pula kesempatan perusahaan tersebut untuk berhasil. Proses pemuasan pelanggan memang tidak mudah, mereka yang terlibat dalam hal ini haruslah mempunyai kreativitas dan inovasi yang baik sehingga pelanggan dapat terpuaskan.

\subsection{Pengukuran Tingkat Kepuasan Pelanggan}

Dalam penelitian ini digunakan metode deskriptifkuantitatif. Untuk menjawab perumusan masalah mengenai sampai sejauh mana tingkat kepuasan alumni terhadap kinerja Pelayanan Program Studi Manajemen Informatika digunakan ImportancePerformance Analysis atau Analisis Tingkat Kepentingan dan Kinerja/Kepuas-an Pelanggan. Importance Performance Analysis (IPA) adalah sebuah teknik analisis deskriptif yang diperkenalkan oleh John A. Martilla dan John C. James tahun 1977. Importance Performance Analysis adalah suatu teknik analisis yang digunakan untuk mengidentifikasi faktor-faktor kinerja penting apa yang harus ditunjukkan oleh suatu organisasi dalam memenuhi kepuasan para pengguna jasa mereka (konsumen). Awalnya, Martilla dan James memaksudkan metode ini untuk digunakan dalam bidang riset pemasaran dan perilaku konsumen. Kendati demikian, pada perkembangan selanjutnya, kini penggunaannya telah meluas pada riset-riset pelayanan rumah sakit, pariwisata, sekolah, bahkan hingga analisis atas kinerja birokrasi publik (pemerintahan). Dalam hal ini digunakan skala 4 tingkat (Likert) yang terdiri dari :

Tabel 2.1 Skala Penilaian

\begin{tabular}{|l|l|l|}
\hline $\begin{array}{l}\text { Kriteria } \\
\text { Kinerja/Pelak } \\
\text { sanaan }\end{array}$ & $\begin{array}{l}\text { Kriteria } \\
\text { Harapan/Kepentingan }\end{array}$ & Skor \\
\hline Sangat Setuju & Sangat Penting & 4 \\
\hline Setuju & Penting & 3 \\
\hline Biasa Saja & Biasa Saja & 2 \\
\hline Tidak Setuju & Tidak Penting & 1 \\
\hline
\end{tabular}


Pemberian skor untuk masing-masing jawaban kinerja program studi manajemen informatika dan harapan alumni bertujuan untuk mempermudah pengolahan data. Berdasarkan hasil penilaian tingkat harapan/kepentingan dan hasil penilaian kinerja/kepuasan maka akan dihasilkan suatu perhitungan mengenai nilai rata-rata harapan dan rata-rata kinerja . Dalam penelitian ini terdapat dua buah variabel yang diwakilkan oleh huruf $\mathrm{X}$ dan $\mathrm{Y}$, di mana $X$ merupakan tingkat kinerja layanan, sedangkan Y merupakan tingkat kepentingan alumni.

Adapun rumus yang digunakan adalah :

$$
T k i=X i /_{Y i} \quad X \quad 100 \%
$$

dimana :

$$
\begin{array}{ll}
\text { Tki } & \text { : Tingkat Kesesuaian responden } \\
\mathrm{Xi} & \text { : Skor Penilaian Kinerja PSMI } \\
\text { Yi } & \text { : Skor Penilaian Kepentingan } \\
\text { Alumni } &
\end{array}
$$

Selanjutnya sumbu mendatar (X) akan diisi oleh skor tingkat pelaksanaan,sedangkan sumbu tegak (Y) akan diisi oleh skor tingkat kepentingan.Dalam penyederhanaan rumus,maka untuk setiap faktor yang mempengaruhi kepuasan pelanggan dengan :

$$
\bar{X}=\Sigma X i / n
$$

$$
\bar{Y}=\Sigma Y i / n
$$

dimana :

$$
\begin{array}{ll}
\overline{\mathrm{X}} & : \text { Skor rata-rata tingkat kinerja pelaksanaan } \\
\overline{\mathrm{Y}} & : \text { Skor rata-rata tingkat Kepentingan/harapan } \\
\mathrm{n} & : \text { jumlah responden }
\end{array}
$$

Diagram kartesius merupakan suatu bangun yang dibagi atas empat bagian yang dibatasi olasi oleh dua buah garis yang berpotongan tegak lurus pada titk-titik (X, Y), di mana $\mathrm{X}$ merupakan rata-rata dari rata-rata skor tingkat pelaksanaan atau kepuasan alumni seluruh faktor atau atribut, dan Y adalah ratarata dari rata-rata skor tingkat kepentingan seluruh faktor yang mempengaruhi kepuasan pelanggan/alumni.

Rumus selanjutnya :

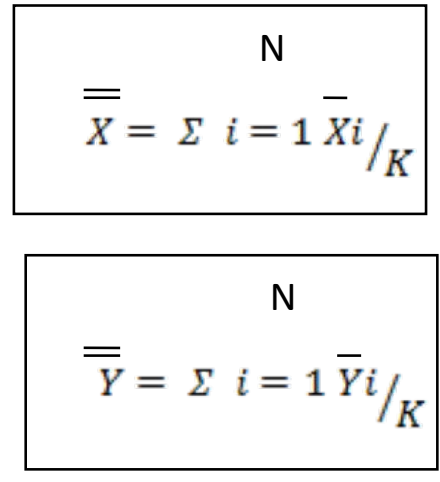

dimana

K : Banyaknya atribut yang dapat mempengaruhi kepuasan pelanggan

Selanjutnya tingkat unsur-unsur tersebut akan dijabarkan dan dibagi menjadi empat bagian ke dalam diagram kartesius seperti pada gambar berikut:

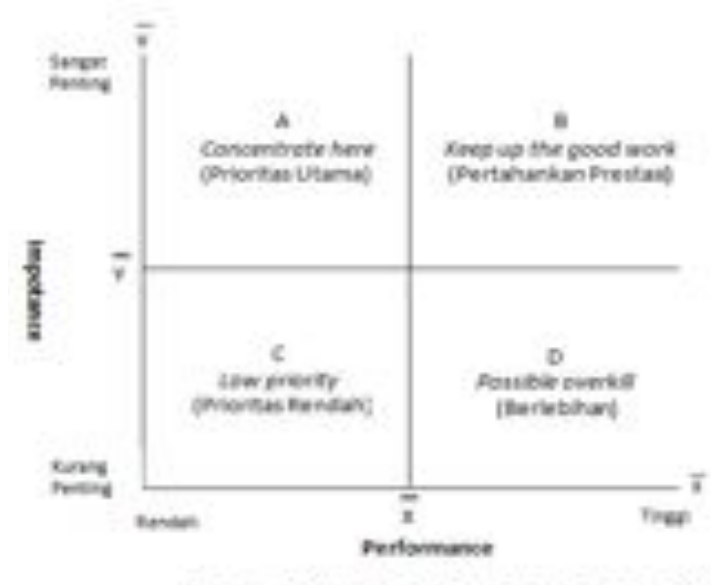

Gambar Diagram Kartesius

(Sumber: John A. Martilla and John C. James, 1977)

Keterangan :

A. Menunjukkan faktor atau atribut yang dianggap mempengaruhi kepuasan pelanggan, termasuk unsurunsur jasa yang dianggap sangat penting, namun manajemen belum melaksanakannya sesuai keinginan pelanggan. Sehingga mengecewakan/tidak puas.

B. Menunjukkan unsur jasa pokok yang telah berhasil dilaksanakan perusahaan, untuk itu wajib di-pertahankannya. Dianggap sangat penting dan sangat memuaskan. 
C. Menunjukkan beberapa faktor yang kurang penting pengaruh-nya bagi pelanggan, pelaksanaan oleh perusahaan biasa-biasa saja. Dianggap kurang penting dan kurang memuaskan.

D. Menunjukkan faktor yang mem-pengaruhi pelanggan kurang penting, akan tetapi pelaksanaannya berlebihan. Dianggap kurang penting tetapi sangat memuaskan.

\section{PERANCANGAN SISTEM}

\subsection{Analisis Sistem}

Analisis sistem merupakan tahap pertama dalam mengembangkan perangkat lunak dengan metode waterfall. Pada tahap ini dilakukan pengumpulan fakta, menganalisis fakta-fakta tersebut, kemudian mengomunikasikannya melalui laporan analisis sistem. Temuan-temuan tersebut digambarkan menggunakan diagram-diagram tertentu untuk memperjelas alur atau proses yang ada. Langkahlangkah yang dilakukan dalam menyelesaikan masalah

digambarkan pada gambar blok diagram berikut ini:

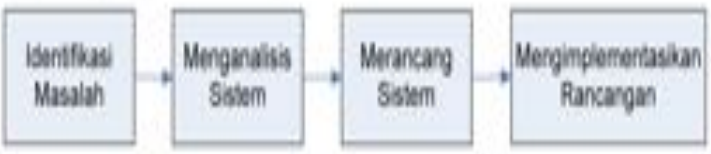

Gambar Tahap-tahap Analisis Sistem

\subsection{Kerangka Konsep}

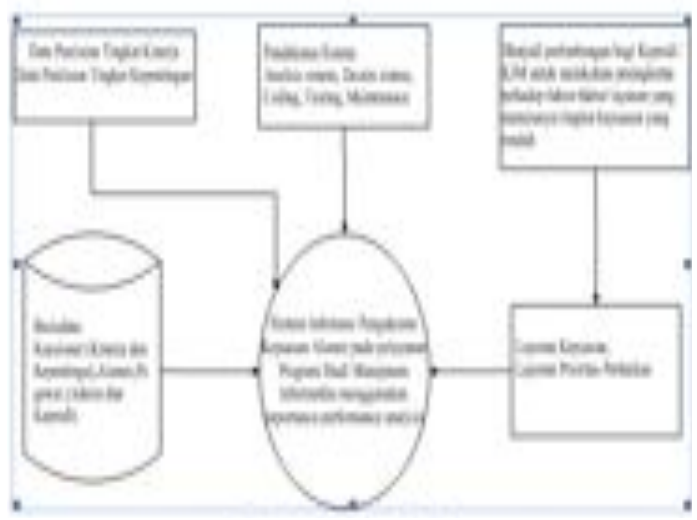

Gambar Kerangka Konsep

\subsection{Perancangan Sistem}

\subsubsection{Diagram Konteks}

Pengguna sistem informasi alumni ada tiga actor yaitu: admin, alumni,kaprodi

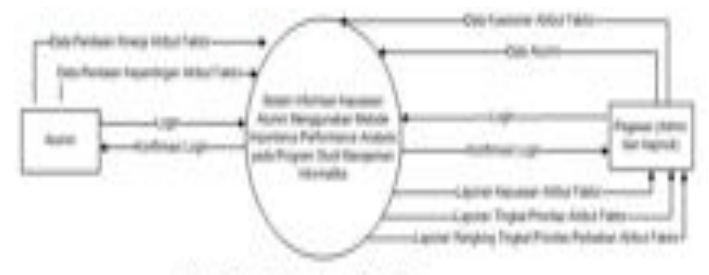

\section{PEMBAHASAN}

4.1 Halaman Awal

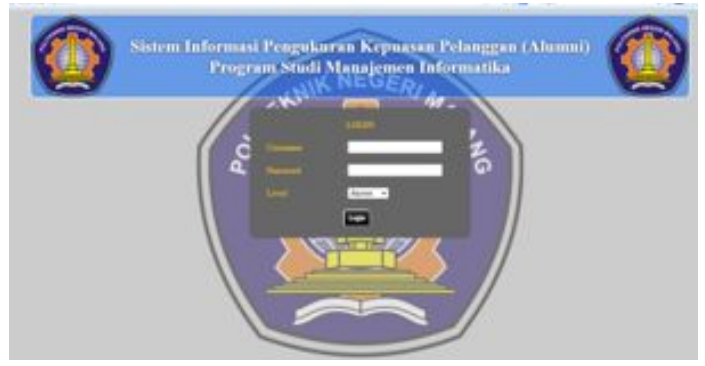

Melalui halaman awal tersebut pengunjung website dapat login, bagi alumni untuk mengisikuesioner kinerja maupun kuesioner tingkat kepentingan,sedangkan untuk admin dan kaprodi digunakan untuk melihat hasil kepuasan alumni dan membuat kuesioner kepuasan yang mempengaruhi kepuasan alumni.

\subsection{Halaman Kuesioneruntuk Alumni}

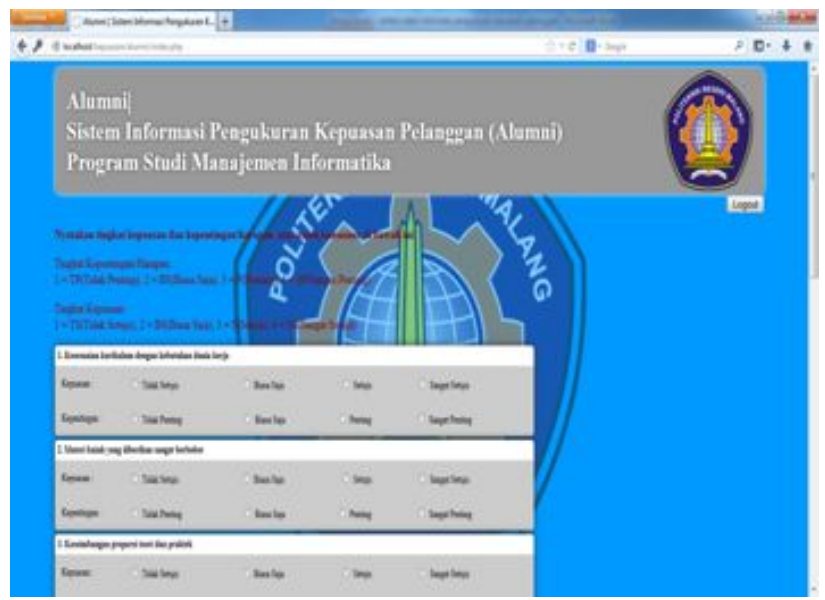

Halaman ini terdiri dari 2 (dua) jenis penilaian kuesioner dalam satu pertanyaan yaitu: penilaian kinerja (performance) dan penilaian kepentingan (importance) 


\subsection{Halaman Hasil Penilaian Tingkat Kepentingan Dan Tingkat Kinerja}

\begin{tabular}{|c|c|c|c|}
\hline Squan= & Qnesten & 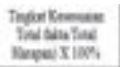 & 64 \\
\hline 1 & 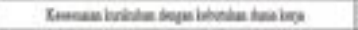 & MLswambans & 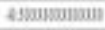 \\
\hline 2 & 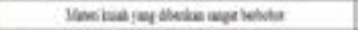 & Eserowews & At \\
\hline 1 & 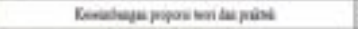 & พอะ:อlstes & 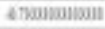 \\
\hline t & 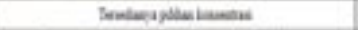 & Nencusans & 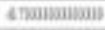 \\
\hline 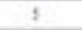 & 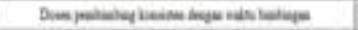 & Malowieas & 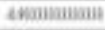 \\
\hline 1 & 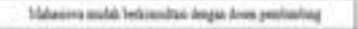 & Bgeiswientis & ckanianam \\
\hline+ & 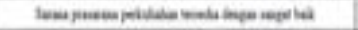 & tacentiens: & 4 \\
\hline i & 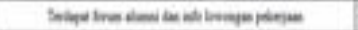 & Mrsitiuasts & 4 \\
\hline , & 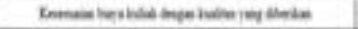 & 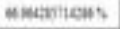 & 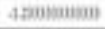 \\
\hline 18 & 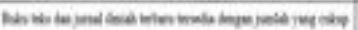 & "1mimatis & 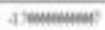 \\
\hline
\end{tabular}

Penilaian alumni dari kuesioner-kuesioner yang disediakan pada halaman kuesioner akan diolah dengan menggunakan metode ImportancePerformance Analysis dan akan menghasilkan tingkat kepuasan dalam bentuk persentase seperti gambar diatas ,sedangkan untuk memperoleh hasil tingkat prioritas perbaikan dengan tambahan menggunakan metode diagram kartesius, dengan rumus sebagai berikut :
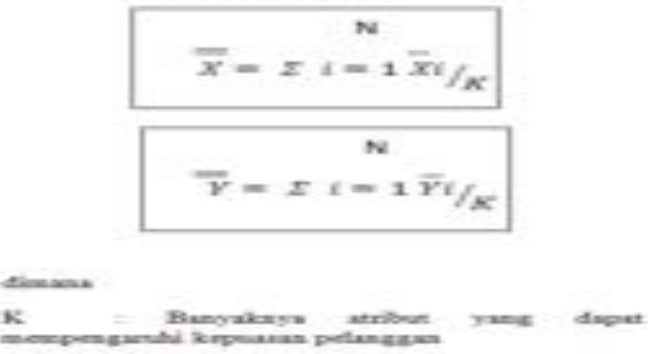

Pada sistem akan nampak seperti dibawah ini :

Hasil jika $(\mathrm{x}<\mathrm{X}$ and $\mathrm{y}>\mathrm{Y})=$ Prioritas Utama, jika $(\mathrm{x}<\mathrm{X}$ and $\mathrm{y}<\mathrm{Y})=$ Prioritas Rendah, jika $(\mathrm{x}>\mathrm{X}$ and $y>Y)=$ Pertahankan Prestasi , jika $(x>X$ and $y<Y)$ $=$ Berlebihan

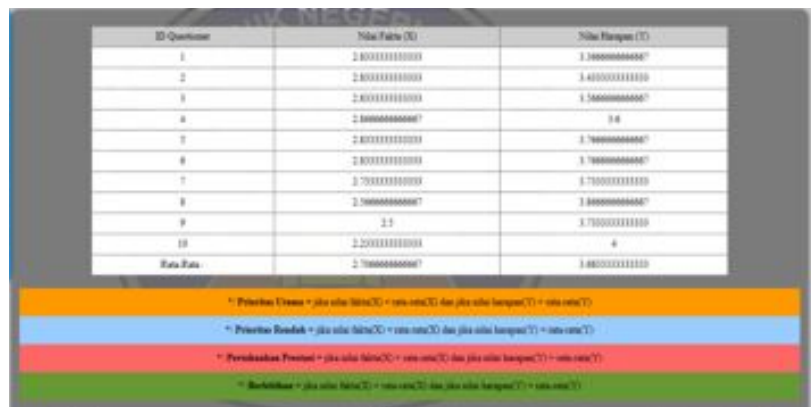

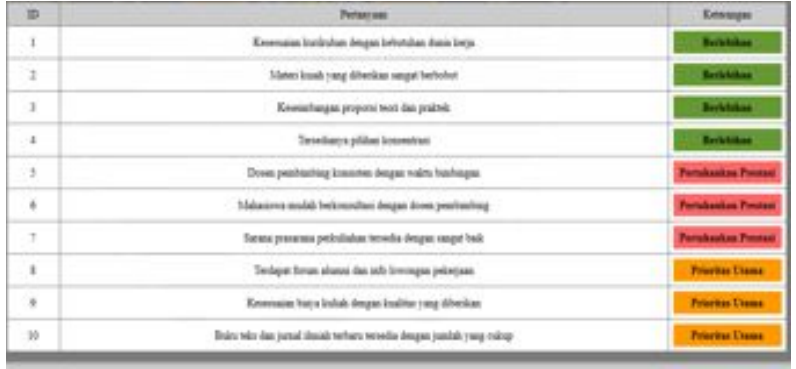

\section{IV.KESIMPULAN}

Dari uraian yang telah dijelaskan pada bab-bab sebelumnya, maka dapat diambil kesimpulan mengenai Sistem Informasi Pengukuran Kepuasan Alumni Menggunakan Metode Importance Performance Analysis pada Program Studi Manajemen Informatikasebagai sarana untuk mengukur kepuasan alumni terhadap kinerja layanan program studi manajemen informatika Politeknik Negeri Malang berprestasi yaitu bahwa :

1. Aplikasi ini dapat mempermudah alumni dalam memberi penilaian terhadap kinerja dan harapan pelayanan program studi manajemen informatika politeknik negeri Malang, sehingga memberi kecepatan ,keakuratan dan efisiensi waktu dalam proses pengolahan data dan informasi..

2. Aplikasi ini dapat mengukur kepuasan pelanggan dalam hal ini alumni terhadap kinerja pelayanan program studi manajemen informatika politeknik negeri Malang dengan menggunakan metode Importance-Performance Analysis.

3. Aplikasi ini dapat menentukan tingkat prioritas perbaikan terhadap kinerja pelayanan program studi manajemen informatika.

4. Aplikasi ini dapat mempermudah pogram studi manajemen informatika dalam mengambil langkah perbaikan terhadap mutu kinerja pelayanan berdasarkan penilaian alumni.

\section{SARAN}

Saran yang dapat diberikan sebagai tindak lanjut dari hasil penelitian adalah sebagai berikut:

3. Aplikasi Sistem Pengukuran Kepuasan Alumni ini bisa dikembangkan lagi tidak hanya untuk mengukur kepuasan alumni namun juga digunakan untuk pengukuran kepuasan pelanggan manajemen informatika yang lain misal mahasiswa,dosen,dunia usaha dan industri.

4. Keterbatasan akan metode yang dipakai dalam sistem yaitu metode importance performance analysis ,apabila penilaian alumni sama atau rata terhadap atribut kuesioner tingkat kepentingan ataupun tingkat kinerja, sistem belum bisa memberi 
informasi tingkat prioritas perbaikan, sistem pengukuran kepuasan pelanggan ini dapat dikembangkan dengan menggunakan metode lain untuk mencapai hasil yang maksimal.

5. Penilaian alumni yang sama atau rata terhadap semua atribut kuesioner tingkat kepentingan ataupun tingkat kinerja pelayanan,ini menunjukan bahwa penilaian alumni tidak realistis,supaya pengukuran kepuasan alumni ini benar-benar dihasilkan dari penilaian yang real dengan keadaan yang sebenarnya pada sistem ini diperlukan penyaringan penilaian yang demikian.

6. Atribut kuesioner kepuasan yang sudah pernah diteliti atau ditanyakan terhadap responden alumni dan menghasilkan tingkat kepuasan yang tinggi maka pada penelitian selanjutnya atribut kuesioner tersebut tidak akan masuk pada sistem kembali, perlu untuk dimenambahkan histori atribut kuesioner supaya admin hanya menambahkan atau merubah atribut kuesioner yang sudah dirasa memuaskan oleh responden alumni dengan kuesioner baru yang perlu untuk diteliti.

\section{VII.DAFTAR PUSTAKA}

Jogiyanto, HM. 2005. Analisis \& Desain Sistem Informasi: Pendekatan Terstruktur, Teori, dan Aplikasi Bisnis, Edisi Ketiga. Yogyakarta: Andi.

M. Shofiyuddin dan Amalia Ilmiani. 2012. Analisa Tingkat Kepuasan Alumni Terhadap Kualitas Pelayanan Fakultas Ekonomi Universitas Pekalongan.

Patty. 2009. Sistem Informasi Kepuasan Pelanggan Terhadap Tabungan Mutiara (studikasus: PT. Bank Maluku).

Djaslim Saladin. 2003. Manajemen Pemasaran.Bandung: Linda Karya.

Griffin, Jill. 2005. Customer Loyalty, Edisi Revisi. Jakarta: Erlangga

Irawan, Handi. 2003. Prinsip-prinsip Kepuasan Pelanggan. Jakarta: Penerbit Elek Media Komputindo. 